\title{
Power Quality Improvement of 33-Bus Distribution System using DSSC
}

\author{
Aarthi Suriya, Anitha, Sampath Kumar, S.Sherine
}

\begin{abstract}
This paper manages displaying and reenactment of Thirty Three Bus Distribution System(TTBDS) utilizing a DSSC. DSSC comprises of a DC source, inverter and infusion transformer. The DSSC is fit for improving the voltage profile of appropriation framework by infusing a voltage in arrangement with the line.Four number of DSSCs are proposed for TTBDS to improve the voltage profile. The TTBD Systems with and without DSSC are demonstrated, recreated and their outcomes are introduced. The outcomes demonstrate that the voltage profile is improved by utilizing DSSC. [19],[20],[21]

Keywords : Unified power flow control(UPFC), Distributed static series compensator(DSSC), Flexible AC Transmission System(FACTS), Voltage Ampere Reactive(VAR), Dynamic Voltage Regulator(DVR),Static Compensator(STATCOM).
\end{abstract}

\section{INTRODUCTION}

Over the trendy couple of a long time, the standard stresses of the strength affiliations are about strength nice troubles. the short evaluate which both the intrigue and delivery of electrical power impact at the presentation of electrical contraption is referred to as power pleasant. From the purchaser perspective, any issue arise approximately modern, voltage or the repetitive deviation that outcomes in electricity sadness is called control pleasant issues. The power great development typically affect by way of the strength instruments used by customers and used in statistics devices.

maximum real hazards for volatile rigging in electrical systems are voltage hangs (voltage dive) and swells (over voltage) [5]. those worrying impacts happen by means of beliefs of express activities, e.g., bog down the shape, inrush streams associated with the begin of giant machines, or buying and selling assignments the cross section on this paper, a allotted static strategy compensator, displayed in as every other records contraption, is used to ease voltage and contemporary waveform deviation and enhance manipulate quality in not extra than seconds. The DSSC shape is gotten from the UPFC shape this is joined one converter and some immaterial loose route of motion converters, as confirmed up in Fig.1.1 [6][4]. The converter takes after the STATCOM even as the method converter uses the D-records thought. The DSSC has same point of confinement as UPFC to modify the

Revised Manuscript Received on August 22, 2019.

S.Aarthi Suriya, Department of EEE,Bharath Institute of Higher Education and Research, Tamilnadu, India. Email: aarthisuriya2703@gmail.com

Anitha Sampathkumar, Department of EEE,Bharath Institute of Higher Education and Research, Tamilnadu, India. Email: anithababs@gmail.com

S.Sherine, Department of EEE,Bharath Institute of Higher Education and Research, Tamilnadu, India. Email: nssherine@gmail.com road parameters, i.e., line impedance, transmission part, and transport voltage size.[4]

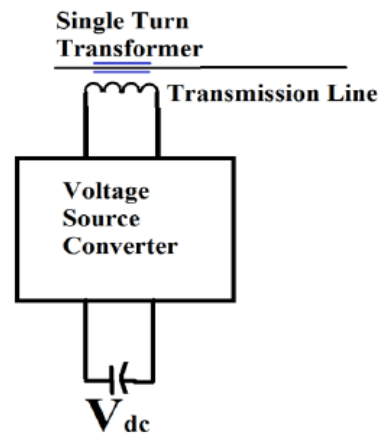

Figure-1: DSSC structure

\section{II.DSSC PRINCIPLE}

inside the Unified strength drift Controller (UPFC) is made from SSSC and STATCOM. both are coupled by means of DC hiding away capacitor through techniques for a customary DC interface.. Speculatively the 0.33 , 6th, and ninth consonant repeat can be used to trade dynamic energy the DSSC, that are commonly zero course of action frequencies.. In putting on this the third sounds repeat is picked that's most immaterial zero get-collectively symphonious repeat. in the going with subsections; the DSSC imperative contemplations are defined. [14],[16], [18]

Since the key of unequivocal terms with different frequencies are zero, so the dynamic power condition is given as:

$$
P=\sum_{n=1}^{\infty} V_{n} I_{n} \cos \phi_{n}
$$

where $V$ nand Inare the voltage and contemporary on the $\mathrm{n} t h$ harmonic, solely, and $\phi \mathrm{n}$ is the point between the voltage and cutting-edge at a comparative repeat. situation (1) gives the dynamic strength at one of a kind repetitive elements is self-choice. From the above condition (1),

the modern and voltage in a single repeat has no impact at the dynamic electricity at numerous frequencies. [13], [15] ,[ 17]

The dynamic strength at specific frequencies is limited 
from every different. So via this idea the converter in DSSC can ingest dynamic strength from the framework on the focal repeat and inject the contemporary yet into the move sector at a symphonious repeat.

In setting on this truth, a converter in DSSC can maintain the dynamic electricity in a single repeat and passes on yield manipulate in some other repeat, and moreover as confirmed up via the degree of dynamic power required on the principal repeat, the DSSC technique converter make the voltage at the symphonious repeat there by way of attracting the dynamic strength from consonant components. [8],[10],[12]

because the technique converters of the DSSC are single-kind out, it offers the DSSC the opportunity to govern contemporary in each stage overtly, which confirms that both terrible and zero social occasion clashing current may be examined. additional controllers are progressed to the modern DSSC controller. Their manage trendy is to display the poor and 0 groupings present day through the transmission line and to constrain them to 0 .

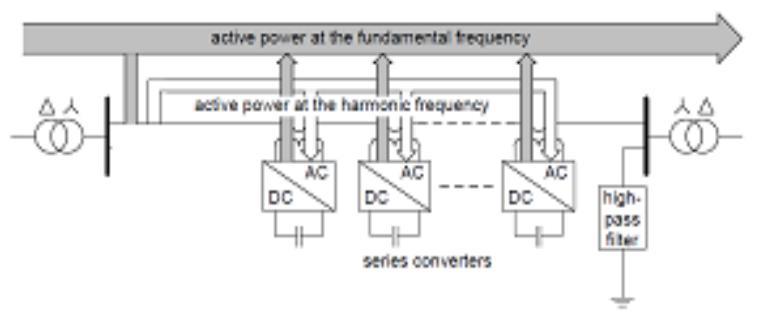

Figure-2.: Active Power Exchange

The above literature does not use DSSC for distribution systems. This work proposes DSSC for TTBS. The comparison of performance of TTBS with and without DSSC is not reported in the previous papers.

\section{III.SYSTEM DESCRIPTION}

Proposed circuit Diagram of DSSC is appeared in Fig 1.3. 33 Bus system is shown in Fig 1.4.

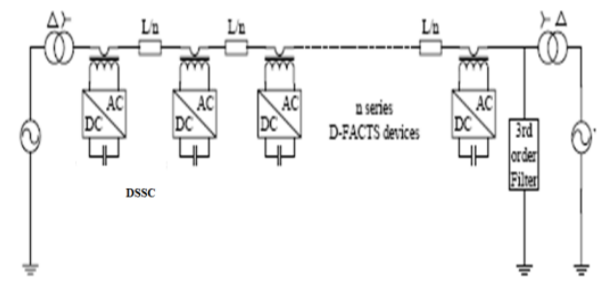

Figure 3 Proposed circuit Diagram of DSSC

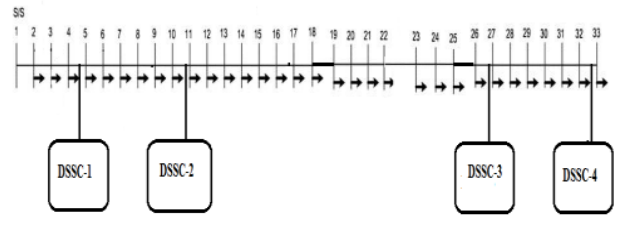

Figure 4 33-Buses System of block diagram

\section{Simulation Results}

Circuit diagram of 33-bus system without DSSC is appeared in Fig 2.1.

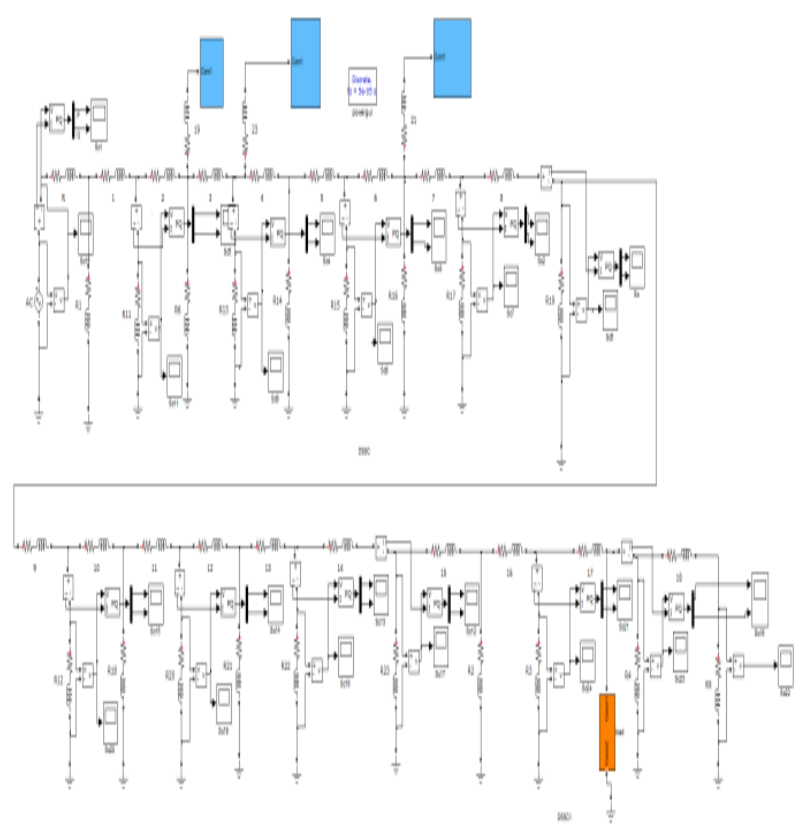

Fig 5 Circuit diagram of 33-bus system without DSSC

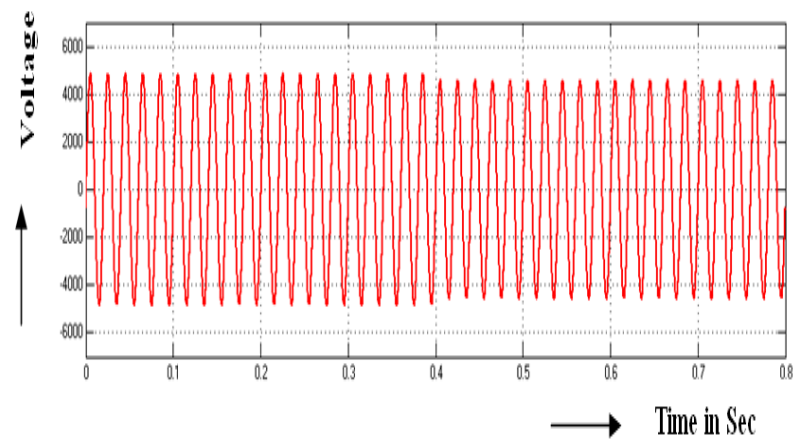

Fig 6 Voltage at bus-5

Voltage at bus-5 is appeared in Fig 2.2 and its gain is $5000 \mathrm{~V}$. Real power and reactive power at 
bus-5 are appeared in Figs 2.3 and its value of real power is $1.17 * 10^{5} \mathrm{MW}$ and its value of reactive power is $2.3 * 10^{4}$ MVAR. Without DSSC after $0.4 \mathrm{sec}$ second load will be on voltage, real and reactive power decreased. [7],[9],[11]

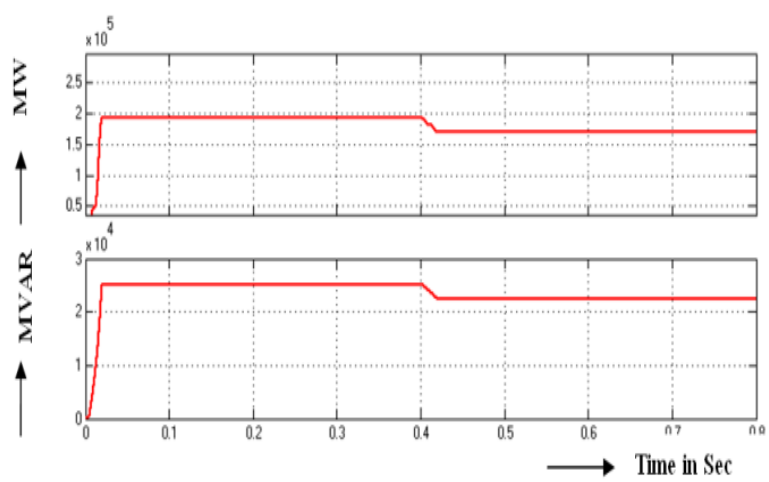

Fig 7 Real power and reactive power at bus- 5

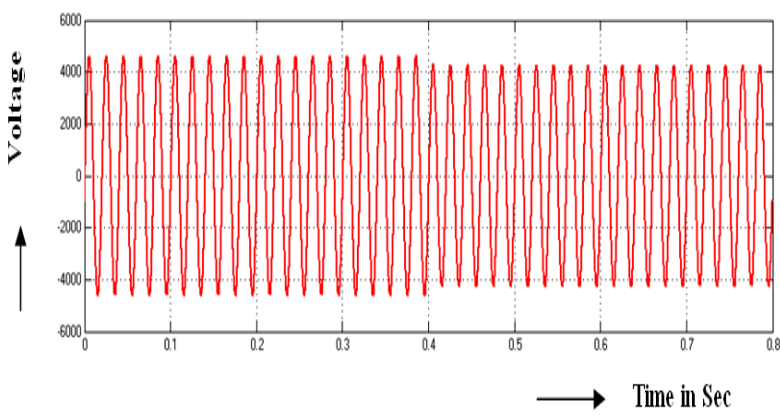

Fig 8 Voltage at bus-26

Real power and reactive power at bus-26 are appeared in Figs 2.5 and its value of real power is $14^{*} 10^{4} \mathrm{MW}$ and its value of reactive power is $4.4 * 10^{4}$ MVAR. Without DSSC after $0.4 \mathrm{sec}$ second load will be on real and reactive increased

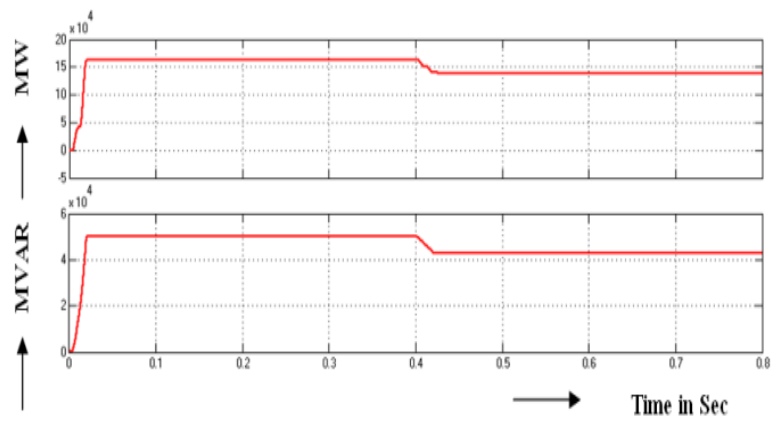

Fig 9 Real and reactive power at bus-26

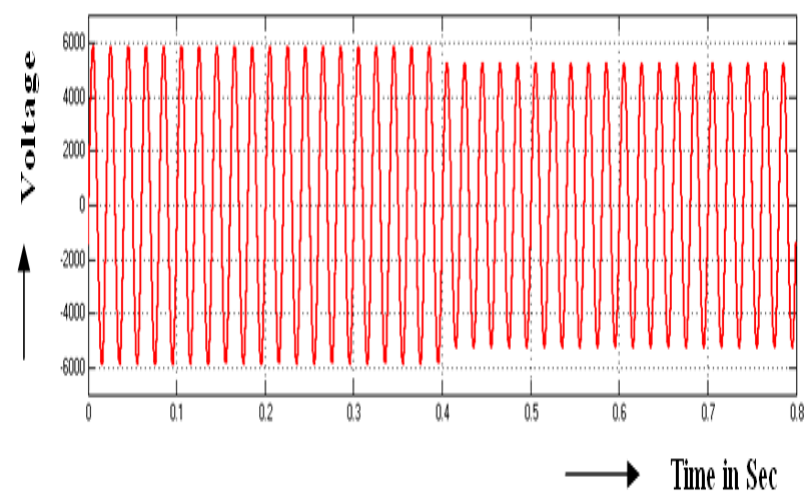

Fig 10 voltage at bus-32

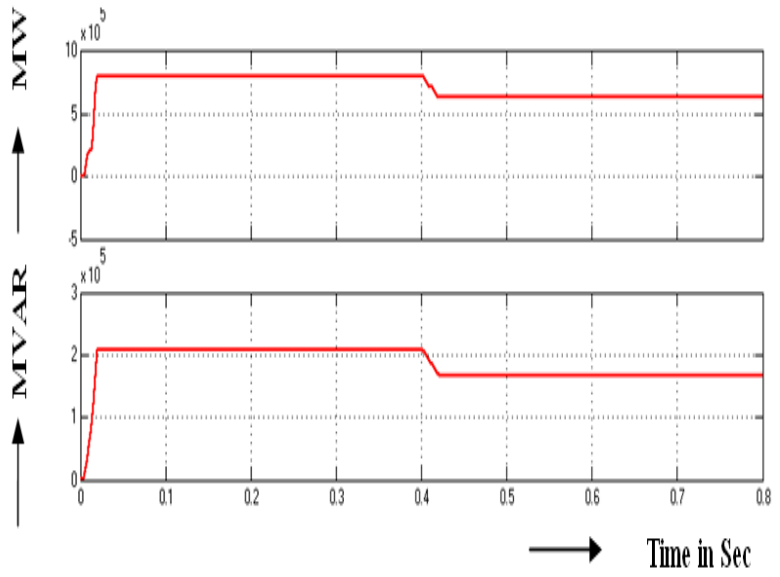

Fig 11 Real and reactive power at bus-32
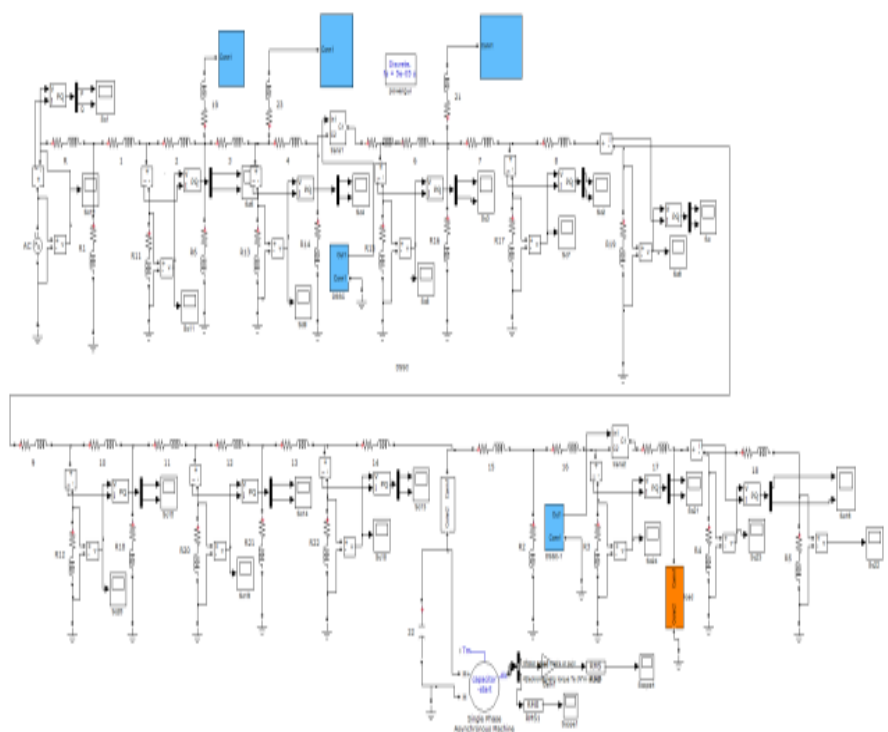

Fig 12 Circuit diagram of 33-bus system with DSSC is appeared in Fig 12 

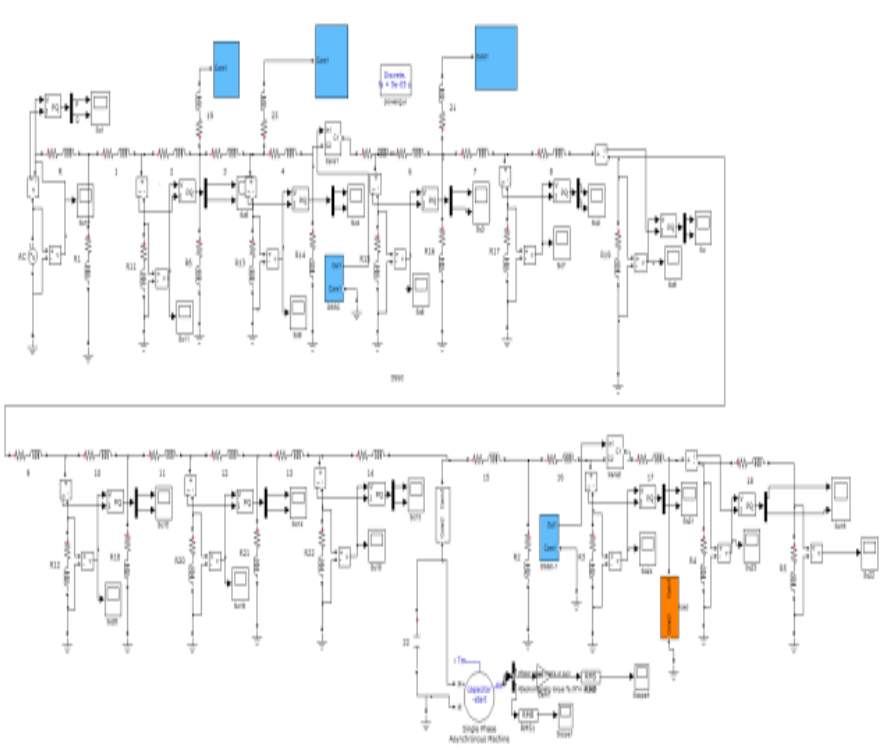

Fig 13 Circuit diagram of 33-bus system with DSSC

Voltage at bus-5 is appeared in Fig 2.9 and its value is $5000 \mathrm{~V}$. With DSSC after $0.4 \mathrm{sec}$ second load will be on voltage as increased.

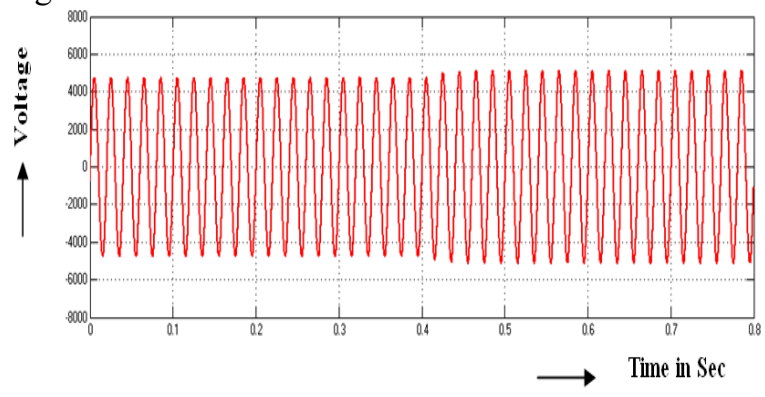

Fig 14 Voltage at bus-5

Real power and reactive power at bus- 5 are appeared in Figs 2.10 and its value of real power is $2.1 * 10^{5} \mathrm{MW}$ and its value of reactive power is $2.8^{*} 10^{4} \mathrm{MVAR}$. With DSSC after $0.4 \mathrm{sec}$ second load will be on real and reactive power increased. [2 ],[4],[6]

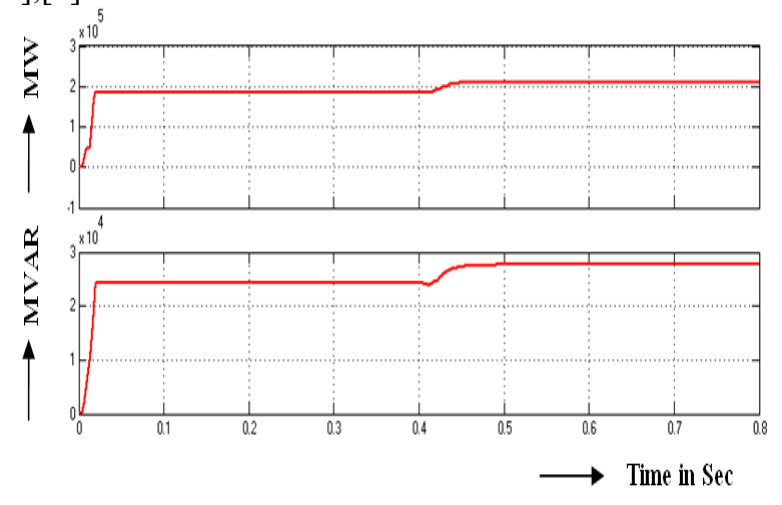

Fig 15 Real and reactive power at bus-5

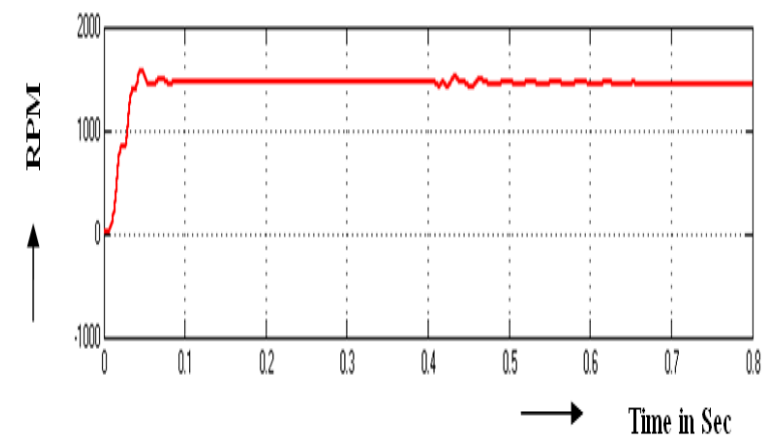

Motor torque at bus-14is appeared in Fig 2.12 and its value is $99 \mathrm{~N}-\mathrm{m}$.

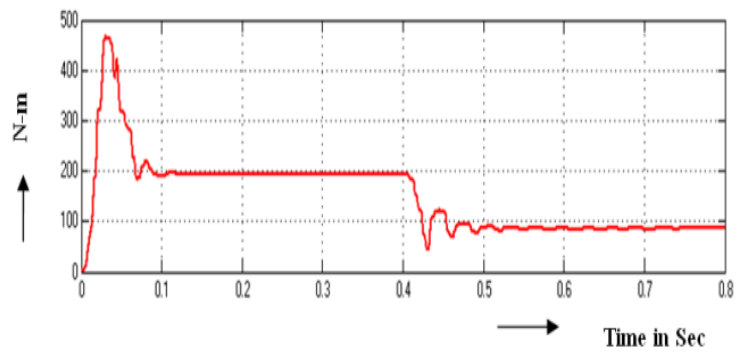

Fig 16 Motor torque at bus-14

Voltage at bus-26is appeared in Fig 2.13 and its value is $5000 \mathrm{~V}$.With DSSC after $0.4 \mathrm{sec}$ second load will be on voltage as increased.

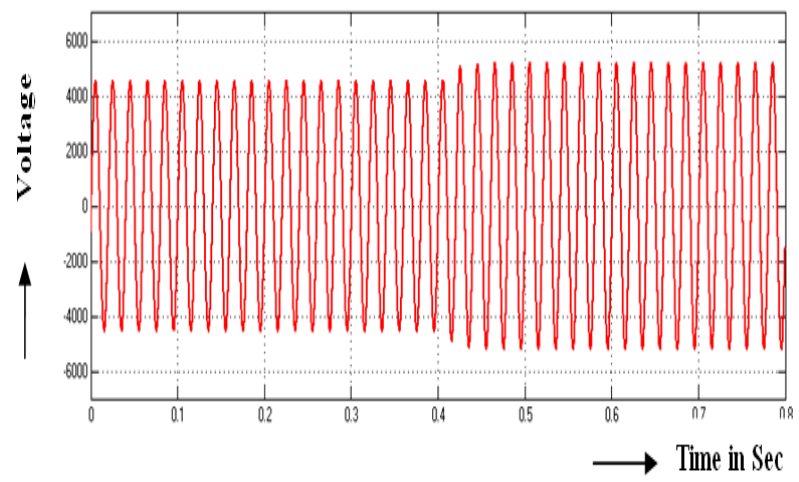

Fig 17 voltage at bus-26

Real power and reactive power at bus-26 are appeared in Figs 2.14 and its value of real power is $2 * 10^{5} \mathrm{MW}$ and its value of reactive power is $6.3^{*} 10^{4} \mathrm{MVAR}$. With DSSC after $0.4 \mathrm{sec}$ second load will be on real and reactive power increased. [1],[3],[5] 


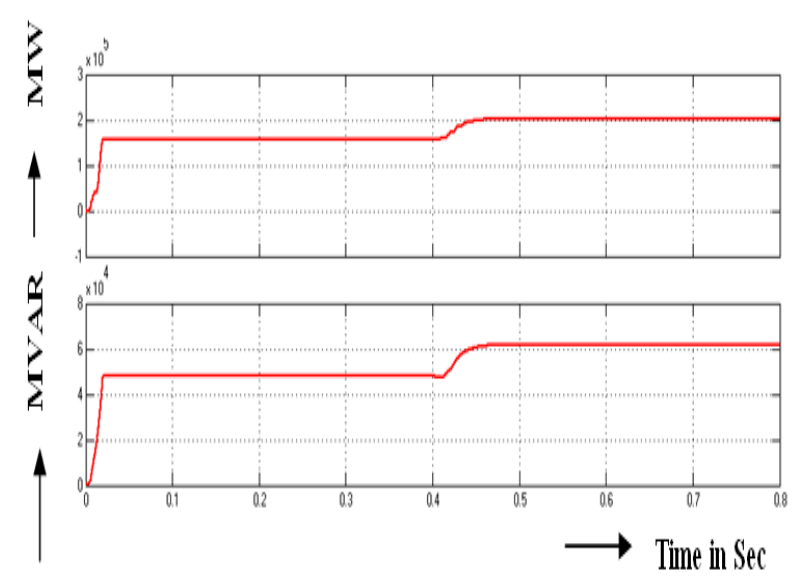

Fig 18 Real and reactive power at bus-26

Motor speed at bus-30is appeared in Fig 2.15 and its value is $1500 \mathrm{RPM}$.

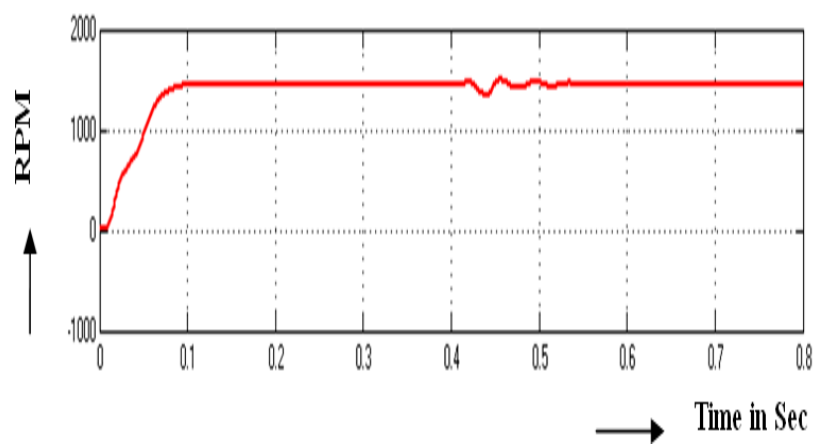

Fig 19 Motor speed at bus-30

Motor torque at bus-30through is appeared in Fig 2.16 and its value is $22 \mathrm{~N}-\mathrm{m}$.

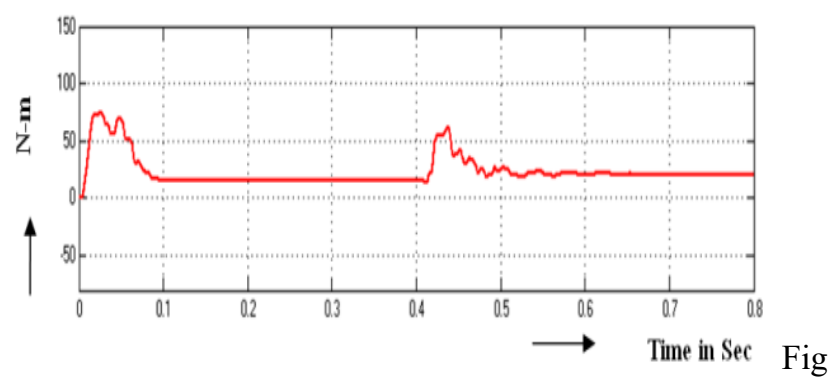

Fig. 20 Motor torque at bus-30

Voltage at bus-32 is appeared in Fig 2.17 and its value is 6300 V. With DSSC after $0.4 \mathrm{sec}$ second load will be on voltage as increased.

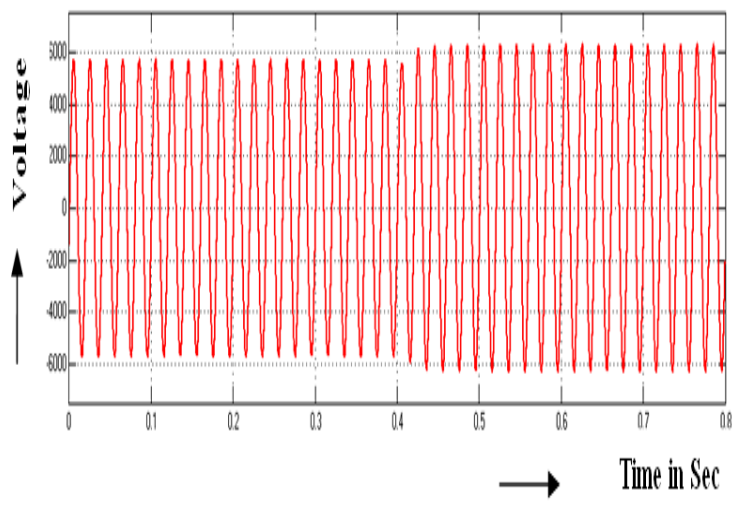

Fig 21 Voltage at bus-32

Real power and reactive power at bus-32 are appeared in Fig 2.18 and its value of real power is $12 * 10^{5} \mathrm{MW}$ and its value of reactive power is $5.5^{*} 10^{5} \mathrm{MVAR}$. With DSSC after $0.4 \mathrm{sec}$ second load will be on real and reactive power increased.

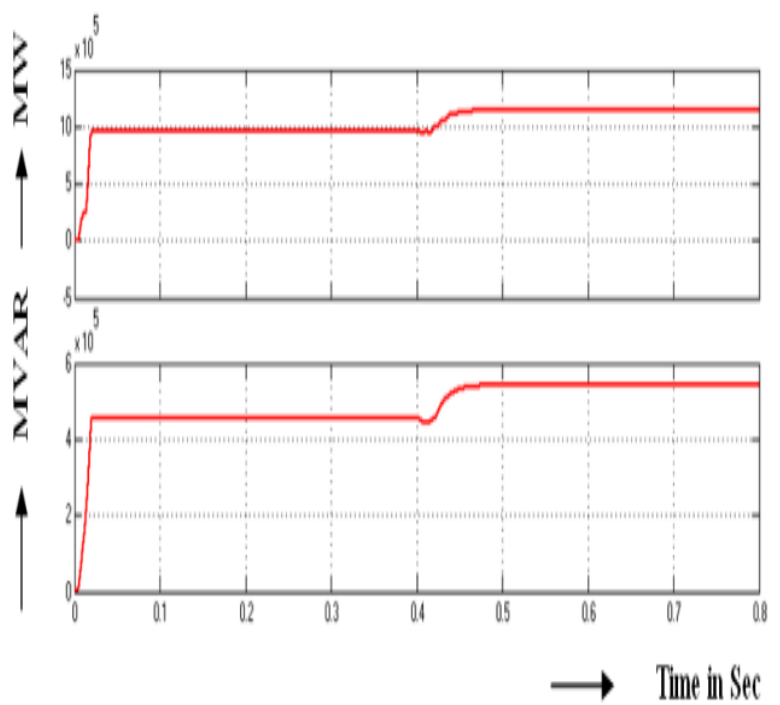

Bus Voltage of without and with DSSC is given in Table-1. DSSC without and with voltage Bus-5 value is 4.55 to $5.51 \mathrm{KV}$. The Bus 26 without and with voltage value is 4.20 to $5.15 \mathrm{KV}$. The Bus 32 without and with voltage value is 5.26 to $6.20 \mathrm{KV}$.

TABLE-1 VOLTAGE OF WITHOUT AND WITH DSSC

\begin{tabular}{|c|c|c|}
\hline $\begin{array}{c}\text { BUS } \\
\text { NO }\end{array}$ & $\begin{array}{c}\text { VOLTAGE } \\
\text { WITHOUT } \\
\text { DSSC (KV) }\end{array}$ & $\begin{array}{c}\text { VOLTAGE } \\
\text { WITH } \\
\text { DSSC(KV) }\end{array}$ \\
\hline BUS-5 & 4.55 & 5.51 \\
\hline $\begin{array}{c}\text { BUS- } \\
26\end{array}$ & 4.20 & 5.15 \\
\hline $\begin{array}{c}\text { BUS- } \\
32\end{array}$ & 5.26 & 6.20 \\
\hline
\end{tabular}


TABLE-2 REAL AND REACTIVE POWER OF WITHOUT AND WITH DPFC

\begin{tabular}{|c|c|c|c|c|}
\hline $\begin{array}{l}\text { BUS } \\
\text { No }\end{array}$ & $\begin{array}{c}\text { Real } \\
\text { power } \\
\text { (MW) } \\
\text { Without } \\
\text { DSSC }\end{array}$ & $\begin{array}{c}\text { Real } \\
\text { power } \\
\text { (MW) } \\
\text { With } \\
\text { DSSC }\end{array}$ & $\begin{array}{c}\text { Reactive } \\
\text { power( } \\
\text { MVAR) } \\
\text { Without } \\
\text { DSSC }\end{array}$ & $\begin{array}{c}\text { Reactive } \\
\text { power( } \\
\text { MVAR } \\
\text { With } \\
\text { DSSC }\end{array}$ \\
\hline $\begin{array}{c}\text { BUS } \\
-5\end{array}$ & 0.170 & 0.215 & 0.024 & 0.028 \\
\hline $\begin{array}{l}\text { BUS } \\
-26\end{array}$ & 0.151 & 0.210 & 0.042 & 0.062 \\
\hline $\begin{array}{l}\text { BUS } \\
-33\end{array}$ & 0.623 & 1.120 & 0.165 & 0.540 \\
\hline
\end{tabular}

\section{CONCLUSION}

TTBS with and without DSSC are simulated. The results indicate that the voltage, real power and reactive power are improved by the addition of DSSC. The increase in $\mathrm{V}, \mathrm{P}$ and $\mathrm{Q}$ are due to increase in voltage with the addition of DSSC. DSSC has the ability to compensate the voltage sag in power and distribution lines. The disadvantage of DSSC is that the hardware cost is increased.

The present work deals with TTBS with and without DSSC. Studies on closed loop TTBS with PI and PR systems will be done in future.

\section{REFERENCES}

[1] Sharma, R.K., Irusapparajan, G. \& Periyaazhagar, D. 2019 "Three-phase symmetric cascading Z-source seven levels multilevel inverter excited by multi carrier sinusoidal pulse width modulation scheme", International Journal of Innovative Technology and Exploring Engineering, vol. 8, no. 10, pp. 4269-4274

[2] Velavan, R., Bharanidharan, S. \& Sheeba, B. 2019, "EMF pollution Causes, effects and protection", International Journal of Innovative Technology and Exploring Engineering, vol. 8, no. 9 Special Issue 3, pp. 1166-1168.

[3] Saravana, S., Balaji, S., Arulselvi, S. \& John Paul Praveen, A. 2019, "Reliable power quality monitoring and protection system", International Journal of Innovative Technology and Exploring Engineering, vol. 8, no. 9 Special Issue 3, pp. 644-645.

[4] Tamil Selvan, S. \& Sundararajan, M. 2019, "Performance Parameters of 3 Value 8t Cntfet Based Sram Cell Design Using H-Spice", International Journal of Recent Technology and Engineering, vol. 8, no. 2 Special issue 5, pp. 22-27.

[5] Jac Fredo, A.R., Abilash, R.S., Femi, R., Mythili, A. \& Kumar, C.S. 2019, "Classification of damages in composite images using Zernike moments and support vector machines", Composites Part B: Engineering, vol. 168, pp. 77-86.

[6] Kathiravan, P. \& Govindaraju, C. 2019, "Design and evaluation of ultra gain isolated DC-DC converter for photovoltaic system", International Journal of Engineering and Advanced Technology, vol. 8, no. 5, pp. 2646-2651.

[7] Kripa, N., Vasuki, R. \& Kishore Kanna, R. 2019, "Realtime neural interface controlled au-pair BIMA bot", International Journal of Recent Technology and Engineering, vol. 8, no. 1, pp. 992-994.

[8] Mohanraj, Meenaa Kumari, M., Philomina, S. \& Jasmin, M. 2019, "In-situ humidity measurement of hydrogen fuel cell car using MEMS sensor", International Journal of Recent Technology and Engineering, vol. 8 , no. 1, pp. 41-43.

[9] Velmurugan, T. \& Prakash, S. 2019, "Artificial intelligent based distribution automation of swift fault detection isolation and power restoration for HT network", International Journal of Innovative Technology and Exploring Engineering, vol. 8, no. 6, pp. 1-6.

[10] Dwarakesh, K. \& Prem Kumar, G. 2019, "Five-level inverter based sequential boost system using fuzzy logic controller", International Journal of Innovative Technology and Exploring Engineering, vol. 8, no. 6, pp. 12-19.

[11] Anne Gifta, A. \& Hemavathi, G. 2019, "Analysis of grid tied solar PV system using ANFIS Algorithm", International Journal of Innovative Technology and Exploring Engineering, vol. 8, no. 6, pp. 312-316.

[12] Jayavel, R., Rangaswamy, T.R. \& Prakash, S. 2019, "Efficient grid management system with renewable and conventional power sources", International Journal of Innovative Technology and Exploring Engineering, vol. 8, no. 6, pp. 287-289.

[13] Hemavathi, G. \& Maheshwaran, S. 2019, "Proportional resonant controlled high gain step-up converter system with improved response", International Journal of Innovative Technology and Exploring Engineering, vol. 8, no. 6, pp. 317-323.

[14] Periyaazhagar, D. \& Irusapparajan, G. 2019, "Design and completion of asymmetric single phase 27 level cascaded mli for various pwm scheme", International Journal of Innovative Technology and Exploring Engineering, vol. 8, no. 6, pp. 792-797.

[15] Mahalakshmi, V. \& Vijayaragavan, S.P. 2019, "PV based power electronic converters for high voltage DC applications", Internationa Journal of Recent Technology and Engineering, vol. 7, no. 6, pp. 670-674.

[16] Irusapparajan, G., Periyaazhagar, D., Prabaharan, N. \& Rini Ann Jerin, A. 2019, "Experimental verification of trinary DC source cascaded h-bridge multilevel inverter using unipolar pulse width modulation", Automatika, vol. 60, no. 1, pp. 19-27.

[17] Sangeetha, G., Sherine, S., Arputharaju, K. \& Prakash, S. 2019, "On Line Monitoring of Higher Rated Alternator using Automated Generator Capability Curve Administer", Proceedings of the IEEE International Conference on \&amp;quot;Recent Trends in Electrical, Control and Communication\&amp;quot;, RTECC 2018, pp. 176.

[18] Bycil, V.J. \& Wiselin, M.C.J. 2019, "Modeling and analysis of vibration energy harvesting system using piezo stack", International Journal of Mechanical and Production Engineering Research and Development, vol. 9, no. Special Issue 1, pp. 523-533.

[19] Sripada, A., Warrier, A., Kapoor, A., Gaur, H. \& Hemalatha, B. 2018 , "Dynamic lateral balance of humanoid robots on unstable surfaces", International Conference on Electrical, Electronics, Communication Computer Technologies and Optimization Techniques, ICEECCOT 2017 , pp. 539.

[20] Srinivasan, S., Thirumalaivasan, K. \& Sivakumaran, T.S. 2018 "Performance evaluation of double-output luo converters", Journal of Advanced Research in Dynamical and Control Systems, vol. 10, no. 10 Special Issue, pp. 870-878.

[21] Karthikayen, A. \& Selvakumar Raja, S. 2018, "A skellam distribution inspired trust factor-based selfish node detection technique in MANETs", Journal of Advanced Research in Dynamical and Control Systems, vol. 10, no. 13, pp. 940-949.

\section{AUTHORS PROFILE}

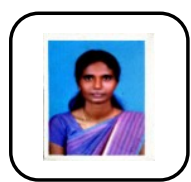

S.Aarthi Suriya, Assistant Professor, Department of EEE, Bharath Institute of Higher Education and Research, Tamilnadu, India.

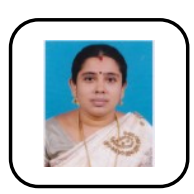

Anitha SampathKumar, Assistant Professor, Department of EEE, Bharath Institute of Higher Education and Research, Tamilnadu, India.

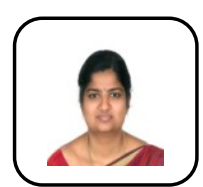

S.Sherine Assistant Professor ,Department of EEE, Bharath Institute of Higher Education and Research, Tamilnadu, India. 